\author{
VERA M. SAVIĆ ${ }^{1}$ \\ UNIVERSITY OF KRAGUJEVAC \\ FACULTY OF EDUCATION IN JAGODINA \\ Department of Philological SCIENCES \\ DaniJela M. Prošić-Santovac ${ }^{2}$ \\ UNIVERSITY OF NOVI SAD \\ FACULTY OF PHILOSOPHY \\ DEPARTMENT OF ENGLISH STUDIES
}

\title{
APPLYING QUALITATIVE METHODS FOR RESEARCH WITH CHILDREN: CHALLENGES AND PROSPECTS OF DOING INTERVIEWS WITH YOUNG AND VERY YOUNG LEARNERS
}

ABSTRACT. Qualitative methods have increasingly been considered as a valuable approach in linguistic research, especially in the area of foreign/second language (L2) learning. In the field of teaching English as L2 to children, qualitative approaches are considered particularly suitable. The paper aims to answer a number of questions relevant to applying qualitative methods for research with children in teaching English as L2 by discussing recent studies conducted in Serbia at primary and pre-primary levels. The method applied in the paper is the analysis of interviews used to study primary learners' L2 reading development (Savić, 2017), and a pre-primary child's L2 progress (Prošić-Santovac, 2017). The former example is a prompted think-aloud protocol interview conducted with twelve 11-year old children for studying a number of issues relevant to their L2 reading skills, while the latter one refers to a structured interview conducted in a case study of using

\footnotetext{
verasavic035@gmail.com

d.prosic.santovac@gmail.com
}

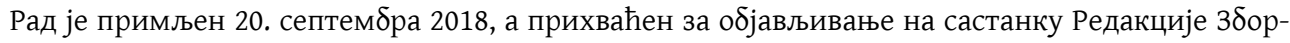
ника одржаном 3. децембра 2018. 
popular video cartoons for teaching English to a four-year-old child. The pedagogical implications of doing research with young and very young learners are summarized as challenges and prospects of using interviews for gaining a deeper understanding of children's L2 development, highlighting a variety of individual and contextual factors affecting the process. It is concluded that, with proper planning and application, qualitative research in general, and interviews in particular, may provide invaluable evidence on the processes of foreign language acquisition and learning.

KEYWORDS: young L2 learners; qualitative research methods; interview; prompted think-aloud protocol interview; case study.

INTRODUCTION

The principal objective of L2 research has been the improvement of classroom practice and enhancement of learning. Considering the complexity of factors affecting L2 learning, the choice of research method is of great importance. Moreover, when doing research with children, both at primary and pre-primary levels, it is crucial to consider ethical issues in all stages of research, from planning, through collecting data, to disseminating research results. The paper first defines qualitative methods and the rationale behind them, and then moves on to the discussion of the use of interviews with young and very young L2 learners, highlighting advantages and challenges of the their application. Finally, the implications of doing interviews with children are discussed through examples of two studies we have recently conducted using a prompted think-aloud protocol interview and a structured interview with twelve 11-year old children and a four-year old child, respectively.

\section{BACKGROUND TO QUALITATIVE RESEARCH METHODS}

Qualitative research "can be taken to refer to research that is based on the descriptive data that does not make (regular) use of statistical procedures" (MacKay \& Gass, 2005, p. 162) and is "valuable in providing in-depth, rich data" (Angouri, 2010, p. 33). It is characterized by its orientation towards the process, rather than product, focus on quality, rather than on quantity, and its inductive approach to data analysis (Eisner, 1998; Greig, Taylor \& MacKay, 2007; MacKay \& Gass, 2005; Merriam, 2009; Patton, 2002). Individuals and events are studied in their natural settings, where categories and further questions emerge from the context. Qualitative studies are interpretive, as the re- 
searchers try to explain and provide reasons for what they have previously described by using an expressive language and focusing on particulars (Eisner, 1998). Descriptions and interpretations are "essential for overall understanding of what has been observed during fieldwork or said in an interview", thus assuming "that the whole is understood as a complex system that is greater than the sum of its parts" (Patton, 2002, p. 59), which makes qualitative research holistic.

The process of doing qualitative research involves several steps (Greig, Taylor \& MacKay, 2007; Merriam, 2009): (1). Conceptualizing a study; (2). Collecting relevant data; (3). Analyzing the data; and (4). Writing up the results. During the first step, the method is determined in terms of the problem, purpose, aims, questions or hypotheses; also, the sample is selected depending on the type of study and on the basis of the criteria established and information required; finally, the instruments are chosen and created accordingly. The second step involves using the instruments to collect data in the way that the same demographic data are gathered from the whole sample, while the other data is usually less structured. A wide variety of different techniques, like ethnographies, interviews, diaries/journals, case studies, and observational techniques can be used to collect data (MacKay \& Gass, 2005). As the major goal of Second Language Acquisition (SLA), a subdiscipline of applied linguistics dealing with L2 classroom research, is to "identify the processes that learners pass through in acquiring a second language, and to identify the processes through which learners acquire the target language" (Nunan, 1990, p. 2), the instruments used for collecting data are chosen accordingly. Ethnographies are used in linguistic qualitative studies mainly for determining cultural patterns, and they "describe and interpret the cultural behaviour, including communicative behaviour, of a group" (MacKay \& Gass, 2005, p. 167). On the other hand, case studies "generally aim to provide a holistic description of language learning or use within a specific population and setting", for describing specific learners within their settings, mainly using longitudinal approach (MacKay \& Gass, 2005, p. 171). Although rich contextualization of a case can shed light on the complexities of L2 learning process, drawing generalizations is very difficult; firmer conclusions about L2 learning can result from combining multiple (longitudinal) case studies, which may provide valuable insights.

Interviews are used in linguistic studies to collect the data that cannot be observed (Patton, 2002), like feelings or "how people interpret the world around them" (Merriam 2009, p. 88). It is crucial that they 
be considered as genuine interaction, not as "a mechanism by which one party (i.e. the interviewer) extracts vital information from another (i.e. the interviewee)" (Edley \& Litosseliti, 2010, p. 165). Open-ended interviews can take three different forms depending on "the extent to which interview questions are determined and standardized before the interview occurs" (Patton, 2002, p. 342): 1. the informal conversational interview, which relies on spontaneously created questions; also called the unstructured interview, in which no list of questions is used, but the questions are developed and adapted to the respondents; 2 . the general interview guide approach, which is determined by a set of issues that will be covered with each respondent; it can be a semistructured interview, in which the researcher uses a written list of questions as a guide, with freedom to probe for more information; and 3. the standardized open-ended interview, which involves carefully prepared and arranged questions for asking each respondent the same questions, in the same order, and using the same words, with minimal probing; it is also called a structured interview. Semistructured interviews with previously set topics are the most commonly used type. There can also be focus-group interviews with participants in groups, with a facilitator who keeps group discussion focused on specific topics. Prompted think-aloud protocol interview "aims to elicit the inner thoughts or cognitive processes that illuminate what's going on in a person's head during the performance of a task" (Patton, 2002, p. 385) by getting the respondents to verbalize what they are thinking and feeling. Most commonly they are based on a reading or writing task, and learners are expected to reflect on their experiences and to describe and discuss them (Mackey \& Gas, 2005). Pilot interviews are usually conducted for trying out the research design and the researcher's own interview techniques, and also for refining the interview questions before their actual use, thus providing valuable experience that may be reflected on and used for revising the research approach (Seidman, 2006, p. 39).

In observations as a qualitative linguistic research technique, the researchers gather data by immersing themselves in a research setting, "systematically observing dimension of that setting, interactions, relationships, actions, events, and so on within it", aiming to collect large amounts of rich data and to "provide careful descriptions of learners' activities", without disturbing them (MacKay \& Gass, 2005, p. 175). The data consist of field notes, impressions and audio and video recordings, for later detailed analysis of language use. In L2 research, observations vary depending on the degree of structure, 
and range from naturalistic studies to classroom observation, and from highly structured (e.g. checklists or rating scales), to less structured (e.g. field notes or transcripts of tapes). However, observations do not provide data on motivations for certain behaviour or actions, and should be combined with other forms of data collection (MacKay \& Gass, 2005). Finally, diaries or journals are verbal protocols in L2 qualitative studies which, like other introspective methods, reveal the learners' internal processes and "yield insights into the language learning process that may be inaccessible from the researcher's perspective alone" (MacKay \& Gass, 2005, p. 178); L2 journals or learner autobiographies allow learners to write about their learning experience, without specific questions being imposed on them.

Analyzing qualitative data is the third step of the qualitative approach, which follows the collection of data performed by using some of the above techniques. Data analysis is the most difficult part of qualitative research, because the data is generally collected in the form of transcribed interviews, fieldnotes, or documents, which first need to be coded by assigning some shorthand designation (words, letters, numbers, phrases, colors) to various aspects of the data (Merriam, 2009). Two data analysis techniques can be used: content analysis and analytic induction; all qualitative data is inductive and comparative, and can be analyzed qualitatively for themes and recurring patterns of meaning. This involves simultaneous coding of raw data and the construction of categories (Merriam, 2009). In inductive data analysis, the researcher aims to get research findings emerging from the frequent, dominant, or significant themes within the raw data, because "inductive data analysis is determined by multiple examinations and interpretations of the data in the light of the research objectives, with the categories induced from the data"(MacKay \& Gass, 2005, p. 179). Cyclical data analysis may involve a new round of data collection that is more focused for "developing theory based on, or grounded in, data that have been systematically gathered and analyzed" (MacKay \& Gass, 2005, p. 179).

The final step in qualitative research is writing up the results. Producing valid and reliable findings ensures impact on practice and "the advancement of knowledge base in the field" (Merriam, 2009, p. xii). Validity and reliability may be ensured through triangulation, member checks, adequate engagement in data collection, peer review, audit trail, rich description, and maximum variation, while generalizability can be left to the reader of the research findings, so that "the person who reads the study decides whether the findings can apply to 
his or her particular situation" (Merriam, 2009, p. 226). Triangulation is the use of a range of different measures, two or more independent data sources, or multiple, independent methods of obtaining data in a single investigation in order to arrive at the same research findings (Patton, 2002). The principal aim of triangulation is to enhance validity and reliability of information and to reduce observer or interviewer bias (MacKay \& Gass, 2005; Patton, 2002). Patton (2002) identifies three components contributing to credibility of qualitative research: a) credibility of the researcher (e.g. training, experience, status); b) rigorous methods (like professional integrity, methodological competence); and c) fundamental appreciation of qualitative inquiry. He argued that the uniqueness of each respondent's answer contributes to credibility of an interview even when the interviewer's questions stay the same for each respondent.

The advantages of applying qualitative methods in L2 research with children have been seen in their significant contribution to uncovering the processes of $\mathrm{L} 2$ learning by collecting the data related to how children understand different aspects of L2 learning (Gheitasi \& Lindgren, 2015). The basic purpose of L2 research with children is to understand and meet their developmental needs (Greig, Taylor \& MacKay, 2007) in L2 classrooms.

DOING INTERVIEWS WITH CHILDREN

Considering the fact that qualitative methods dealing with children's perspectives have only recently started to be considered, it is not strange that using interviews with children has not still become a common practice among researchers (Greig, Taylor \& MacKay, 2007). The researchers' opinion of children being valid research subjects able to express their views is, obviously, changing rather slowly. However, not only do children have a point of view, but they "have a right to express those views freely in all matters affecting them", depending on their maturity and age (Shaw, Brady \& Davey, 2011, p. 4). Even preschoolers are "surprisingly competent in ways not usually appreciated by the researchers", although their communicative abilities are limited if compared to primary-school children (Greig, Taylor, \& MacKay, 2007, pp. 90-91).

Greig, Taylor and MacKay (2007) acknowledge a complex nature of children and offer a qualitative framework for doing research with them in terms of assumptions, methods, questions, contexts, participants, data collection, data analysis and findings. The framework can 
be summarized in the following way: children's nature is subjective, their knowledge is socially constructed, and they are studied in natural contexts as active participants of their social world, by providing perspectives to open-ended questions; data is usually collected in the form of interviews and verbal protocols, and is analyzed to reveal the participants perspectives.

\section{Ethical Aspects of Conducting INTERVIEWS With CHILDREN}

Interviews belong to the three primary means of collecting data in qualitative research, together with observations and documents (Patton, 2002), and their purpose is not to answer questions or to test hypotheses, but to understand the experience of other people and the meaning they attach to it (Seidman, 2006). Great care should be taken to maximize the validity of the children's responses, and check it through observations. Ethical issues related to gathering data from L2 learners are becoming increasingly important (MacKay \& Gass, 2005). When interviews are used with children, children may not be treated in the same way as adults because their abilities, needs and perspectives are different, and they approach research contexts in unique ways. The ethical implications of conducting interviews with children relate to the fact that children are directly involved in research, which requires obtaining informed consent, carefully considering power issues and potential abuse of information gained from interviewing children.

First, the research must be explained in the language that children can understand; second, the child's parents must be informed about the research and a signed consent must be obtained from the parent; and third, the parents and the school board/principal must be assured that research will not negatively affect the L2 learning process, and that there will be a minimal risk to the child's physical and psychological well-being (MacKay \& Gass, 2005). The teacher must assure learners that there will be no extra points or penalties for participation/non-participation in the research. The signed consent "implies voluntary agreement to participate in a study about which the potential subject has enough information and understands enough to make an informed consent" (MacKay \& Gass, 2005, p. 27). The information should explain the procedures, purposes, risks and benefits of the research, as well measures for ensuring anonymity and confidentiality during research and in dissemination of results (MacKay \& Gass, 2005). The written consent should be in the language that both learn- 
ers and parents understand. Participants in the research must know that they have a choice of participation and the right to withdraw from the research at any time, what their role in the research is and what will happen to the data (Greig, Taylor \& MacKay, 2007). Additional approvals by school principals should also be obtained in the form of signed documents allowing the researcher to conduct the research in a school setting. The ultimate aim is to "foster confidence between the research community and the public" (MacKay \& Gass, 2005 , p. 41). The research environment and setting is a significant factor in increasing children's confidence and trust; the children's natural environment, i.e. a secluded place within the school or kindergarten building is the best solution for organizing interviews.

Sound ethical principles should be respected by researchers in relation to direct involvement of children in research by "giving appropriate thought to potential ethical dilemmas and approaching and gaining permission from relevant gatekeepers is essential" before starting to collect data (Greig, Taylor \& MacKay, 2007, p. 181). Interviews "can be conducted in the learner's L1, thus removing concerns about the proficiency of learner impacting the quality and quantity of the data provided" (MacKay \&Gass, 2005, p. 174), and since they are interactive, "researchers can elicit additional data if initial answers are vague, incomplete, off-topic, or not specific enough" (MacKay \& Gass, 2005, p. 173) by asking follow-up questions.

Researchers should be aware of their own interviewing skill. Since unstructured interviews are not easy for novice researchers, they should try to be sensitive to the age, gender and cultural background of the child by making them comfortable at a familiar place, encouraging open-ended discussion, placing the key questions in the middle and mirroring the answers neutrally to provide opportunity for reflection (MacKay \& Gass, 2005). When verbally engaging with children, it is mainly validity that matters as "the accuracy of children's responses largely depends on their developmental capabilities, including their ability to manage the demands of the research tasks used to pose the questions, to cope with one-to-one interviews or group interviews, and their understanding of the reason for the interview" (Greig, Taylor \& MacKay, 2007, p. 91). While interacting with children, the interviewer should remain neutral, avoid ambiguous questions, and ask the questions that have been carefully structured and worded in advance, in order to avoid misunderstandings that may be caused by the children's tendency to take the questions literally (Patton, 2002). Moreover, to further avoid misunderstandings 
and give a child an opportunity to fully convey his/her thoughts, the interview should be conducted in the child's mother tongue and the children should be given enough time to provide answers to interview questions. The age factor is relevant in questioning children: while school children are able to answer 'why', 'when' and 'how' questions, very young learners, i.e. preschoolers aged three to seven, can only make very simple inferences and often need support by using toys for remembering (Greig, Taylor \& MacKay, 2007).

In conclusion, there are unavoidable challenges, difficulties and limitations of doing interviews with primary-school and pre-primary children. If treated properly, with clear focus on the linguistic aspect being studied, these challenges may lead to innovative and improved methodological approaches and interview techniques. Conducting a good interview requires "listening intently and asking questions that focus on concrete examples and feelings rather than on abstract speculations" (Eisner, 1998, p. 183). The prospects of conducting interviews with children lie in listening very carefully to what children have to say about their L2 learning.

\section{PRospects of Conducting INTERVIEWS WITH CHILDREN}

Qualitative research offers many persuasive benefits and is indispensable for doing research with children because "children represent an excellent source of the kind of data that are at the heart of qualitative research - rich descriptions in words and pictures that capture children's experiences and understandings" (Greig, Taylor \& MacKay, 2007 , p. 138). Apart from being very useful as "supplementary sources of data" (Edley \& Litosseliti, 2010, p. 169), interviews may provide a comprehensive insight into the children's own world, consolidate the established knowledge, provide new information and/or perspectives on what is already known, give information on the children's attitudes, motivations, expectations, beliefs, views and understandings, and empower children as individuals whose experiences and understandings matter to other people (Edley \& Litosseliti, 2010; Shaw, Brady and Davey, 2011). Viewed from the constructivist position, the main benefit of interviews lies in "creating a body of data that are indicative and illustrative of particular social phenomena" (Edley \& Litosseliti, 2010, p. 173), thus providing a wealth of specific and detailed information that "increase the depth of understanding" (Patton, 2002 , p. 14). The possibility to choose among six kinds of questions on a selected topic allows the researcher to tailor the interview to the 
aims and the interview context. Patton (2002) distinguishes among the following six types: experience and behaviour questions, opinion and values questions, feeling questions, knowledge questions, sensory questions, and background/demographic questions; any question can be given in one of these types, hence contributing to achieving the depth and comprehensiveness of insight.

Children can play a significant role in improving the quality of research by "helping to identify appropriate methodologies, or creative and innovative ways of collecting data, that are acceptable to their peers, [by] ensuring that research tools are relevant (for example, questionnaires and interview schedules) and issues are approached using language they understand, [and by] enhancing the quality and quantity of data gathered" (Shaw, Brady and Davey, 2011, p. 5). In summary, qualitative research methods in general, and interviews in particular, have a lot to offer to those doing research with children.

\section{PEDAGOGICAL IMPLICATIONS OF DOING INTERVIEWS WITH CHILDREN}

The implications of two recent research studies in which we conducted interviews with children are presented in this section. The method applied is the analysis of interviews used to study primary learners' L2 reading development (Savić, 2017), and a pre-primary child's L2 progress (Prošić-Santovac, 2017). The former example is a prompted think-aloud protocol interview conducted with twelve 11-year old children for studying a number of issues relevant to their reading skills in English as a foreign language, while the latter one refers to a structured interview conducted in a case study of using popular video cartoons for teaching English to a four-year-old child.

\section{Prompted THINK-ALOUd Protocol InTERVIEW WITH Young LEARNERS}

The interview was applied in a wider study of young learners' reading skills in Serbia (Savić, 2014, 2016) with 12 focal learners drawn from six state primary schools in the country. The interviewees were aged 11 (five girls and seven boys), and were purposefully chosen in the process of data collection: they had been nominated by their English language teachers as good readers and eloquent learners who could give extended answers in response to the interview questions (see MacKay \& Gas, 2005; Merriam, 2009), but the criteria like the provision of the parents' consent, the participant's availability at the time of the set interview, and willingness to participate, were also consid- 
ered. The Think-Aloud Protocol interview questions had been designed by the researcher with clear, unambiguous open-ended questions, and the interview was carried out in Serbian, the participants' mother tongue, in the quiet premises of the school, during the school hours. The interviews were audio recorded, and later transcribed for analysis. The participants were made to feel comfortable both about being interviewed and audio recorded; the interviewer assured them that the interviews were conducted for research purposes exclusively, and that their identity would be protected and their answers used as anonymous data. In appreciation of the participants' voluntary participation in the interviews, each interviewee was given a notebook for keeping records of her/his future reading in English.

The interviews were individual and semistructured, in the participants' native language (Serbian), and were audio taped, transcribed verbatim, read and color coded, and finally analyzed for dominant themes. The analysis was done in L1, and then the findings and supporting evidence was translated into English (see Merriam, 2009). The interview consisted of four parts, and the third and fourth ones were partly reported in Savić (2017). They comprised questions related to the parts of the text read concurrently, aiming to elicit the reader's thoughts/cognitive processes going on in the process of reading, as well as the decoding skills used, the cueing systems applied, and the reading difficulties experienced. The first and the second parts of the interview were related to the participant's experiences, attitudes, understandings and beliefs connected to reading in English and to other factors associated with achievement in reading. These parts involved open-ended questions and produced qualitative data for deeper understanding of the development of the beginning reading in English.

Before the interviews were conducted, two pilot interviews had been carried out with 11-year old English language learners drawn from a local primary school. The purpose was twofold: firstly, to help the researcher familiarize with the procedure and with the research questions; secondly, to assist the researcher in detecting any ambiguity in wording of the questions or in their sequence. The pilot interviews helped the researcher improve the interview questions and gain confidence in applying the questions and other prompts in talking to children.

The transcripts of the interviews comprised the data that was analyzed thematically, for recurring themes and issues arising from the answers to interview questions and prompts (see Appendix for sample interviews translated into English). Six big themes were revealed 
by the rich data provided by the respondents (Savić, 2016). First, the participants described their interests in reading and their habits of reading in their free time. Then, they explained their home background and how it affected their reading in English, which was defined as the second theme. The third theme referred to the participants' understanding of the similarities and differences between L1 and L2 reading. The fourth theme involved a set of the participants' $\mathrm{L} 2$ reading strategies, while the fifth theme comprised all types of the reading difficulties identified by the participants in the interview. The final, sixth theme, involved the participants' views of themselves as readers, their self-esteem and their plans for improving their L2 reading skills.

The results showed that all participants were highly motivated to answer the interviewer's questions and provided very rich data about themselves as L2 readers: interest in learning English and reading in English out of school, availability of reading materials in English, extensive reading interests, accessibility of the internet at home, the role of older siblings and parents in developing extensive reading habits and in improving their own reading skills. When asked about the preferred mode of reading, the participants expressed very strong preferences for either oral or silent reading, giving specific reasons for their choices: some needed to hear the English words in oral reading to aid their comprehension, while the others preferred reading silently for the possibility to reread the challenging parts of a text. The interviews showed that the participants' metacognitive awareness about improving L2 reading skills was well developed. It was concluded on the basis of the interviews that successful and less successful readers differed in their motivation for and attitude to reading in English, in their strategic competence, self-confidence, extensive reading habits and planned practice for improving the L2 reading skill.

In conclusion, the challenges of conducting prompted think-aloud protocol interviews experienced in our study were minimized by thoughtful planning, piloting, and excellent organization of the interviews. However, the prospects appeared to be numerous, as it can be seen in the results already described and discussed. The greatest benefit of our interviews was in their potential to engage each respondent in ample, detailed and highly informative contributions to the phenomenon of developing $\mathrm{L} 2$ reading skills. 


\section{STRUCTURED INTERVIEW WITH A VERY YOUNG LEARNER}

In teaching foreign languages to very young learners, motivation is an issue that needs to be considered even more than in the case of any other age group. Invoking intrinsic motivation for learning and catering for the genuine interests of pre-primary children is necessary for achieving success. Therefore, this study aimed to examine whether centering teaching around authentic media material, such as popular cartoons, and the accompanying branded toys, affected the level of L2 knowledge and motivation for learning of a four-year-old child (Prošić-Santovac, 2017). "One environment - one language" approach was developed for this case study, following the L2 linguistic progress during the period of 18 months. Individual structured interview was conducted in the child's mother tongue (Serbian). The interview was based on Berkeley Puppet Interview (Ablow \& Measelle, 1993), it was age-appropriate and interactive for eliciting the child's self-perceptions through the following scales: Self-efficacy scale; Curiosity scale; Involvement scale; Preference for challenge scale; Recognition scale; Social scale; Competition scale; and Compliance scale. Highly motivating materials, like cartoons and toys, were essential for conducting interviews and eliciting L2 verbal reactions of the child.

The results showed that vocabulary acquisition tripled during the period of the study, and that both intrinsic and extrinsic motivations were high, as well as self-efficacy, while scores in competition and compliance were low. The results speak in favour of using this approach both in kindergarten settings, exploiting role play with playschool character toys, and in home settings, where family characters can be used to connect home and pre-primary environments. Engaging materials, make-believe and stories are significant factors in creating the appropriate context for effortless L2 learning of young learners.

The challenges of doing a structured interview with very young children lie in ensuring the appealing quality of materials, and in sustaining children's interest in them. Also, the materials have to be age appropriate and to "grow" with children. If positive experience is provided through interviews, the results of analyzing the collected data may potentially be rather informative of the children's motivations, like in the above study.

CONCLUSION This overview of using qualitative research methods and interviews as qualitative research techniques, has highlighted the basic princi- 
ples of qualitative approaches, while the example studies conducted in the Serbian context have given their possible applications in practice of L2 teaching and learning with the aim of gaining a deeper understanding of the process at different levels, carefully drawing "the links between theory and practice" (Litosseliti, 2010, p. 1). What is more, the data collected in such studies have the potential to be turned into theory.

In spite of the challenges, qualitative studies have great potential in linguistic studies and will become even more important in the future because there is an increased research emphasis on everyday life, quality of life, and the whole person. These holistic interests in well-being and in research conducted in natural settings are central features of qualitative research, and suggest that these approaches will become increasingly important (Greig, Taylor \& MacKay, 2007). Overcoming unavoidable challenges involved in doing interviews with children can be done with careful and detailed planning, to ensure the depth of understanding of the children in their natural settings, like the classroom or a playground. Qualitative studies are seen as powerful and indispensable approaches in L2 studies with young and very young learners.

CORPUS

Savić, V. (2017). Reading Difficulties: What Do We Learn from Young English Language Learners? In: S. Letica Krevelj \& R. Geld (Eds.). UZRT 2016 Empirical Studies in Applied Linguistics (pp. 31-42). Zagreb: FFPress.

Prošić-Santovac, D. (2017). Popular Video Cartoons and Associated Branded Toys In Teaching English To Very Young Learners: A Case Study. Language Teaching Research, 21 (5), 568-588.

REFERENCES

Ablow, J. C. \& Measelle, J. R. (1993). Berkeley Puppet Interview: Administration and Scoring System Manuals. Berkeley, CA: University of California.

Angouri, J. (2010). Quantitative, Qualitative or Both? Combining Methods in Linguistic Research. In L. Litosseliti (Ed.). Research Methods in Linguistics (pp. 29-45). London: Continuum International Publishing Group.

Edley, N. \& Litosseliti, L. (2010). Contemplating Interviews and Focus Groups. In L. Litosseliti (Ed.). Research Methods in Linguistics (pp. 155-179). London: Continuum International Publishing Group.

Eisner, E. W. (1998). The Enlightened Eye: Qualitative Inquiry and the Enhancement of Educational Practice. Upper Saddle River: Prantica Hall. 
Gheitasi, P. \& Lindgren, E. (2015). Broadening the Understanding of the Language Classroom: Mixed Methods. In: E. Lindgren \& J. Enever (Eds.), Språkdidaktik: Research in Language Teaching and Learning (pp. 21-30). Umeå: Umeå University, Department of Language Studies.

Greig, A., Taylor, J. \& MacKay, T. (2007). Doing Research with Children. London: SAGE Publications Ltd.

Litosseliti, L. (Ed.) (2010). Research Methods in Linguistics. London: Continuum International Publishing Group.

MacKey, A. \& Gass, S. M. (2005). Second Language Research: Methodology and design. Mahwah: Lawrence Erlbaum Associates, Inc.

Merriam, S. B. (2009). Qualitative Research: A Guide to Design and Implementation. San Francisco: A Wiley Imprint.

Nunan, D. (1990). Second Language Classroom Research. ERIC Digest. ED321550.

Patton, M. Q. (2002). Qualitative Research and Evaluation Methods (3rd ed.). Thousand Oaks: Sage Publications.

Prošić-Santovac, D. (2017). Popular Video Cartoons And Associated Branded Toys In Teaching English To Very Young Learners: A Case Study. Language Teaching Research, 21 (5), 568-588.

Savić, V. (2014). ). Investigating reading skills of Serbian young learners learning English as a foreign language. In J. Enever, E. Lindgren \& S. Ivanov (Eds.), Conference Proceedings from Early Language Learning: Theory and Practice 2014, pp. 108-114. Umea: Umea University, Sweden.

Savić, V. (2016). Reading difficulties in English as a foreign language. Novi Sad: University of Novi Sad. (unpublished doctoral dissertation)

Seidman, I. (2006). Interviewing as Qualitative Research: A Guide for Researchers in Education and Social Sciences. New York: Teachers College Press.

Shaw, C., Brady, L. \& Davey, C. (2011). Guidelines for Research with Children and Young People. London: National Children's Bureau.

APPENDIX

Sample prompted think-aloud protocol interview (I=Interviewer; P= Participant)

\begin{tabular}{|l|l|}
\hline & PARTICIPANT: L-5-1-1-27 \\
\hline I & $\begin{array}{l}\text { What do you think about the length of the story? Is it appropriate? Or maybe it should be longer } \\
\text { or shorter? }\end{array}$ \\
\hline P & No, no. It is just the appropriate length. \\
\hline
\end{tabular}




\begin{tabular}{|l|l|}
\hline I & $\begin{array}{l}\text { If you had more stories like this one, how often would you be able to read them at home after } \\
\text { classes? }\end{array}$ \\
\hline P & Only at weekends; not as often as I read in Serbian because there would be new words in it. \\
\hline I & What would you do to understand new words? \\
\hline P & $\begin{array}{l}\text { I don't know, I'd look them up on the internet or in a dictionary, or I may understand them } \\
\text { without help. }\end{array}$ \\
\hline I & $\begin{array}{l}\text { What do you usually do when you encounter an unfamiliar word that you want to learn? Do you } \\
\text { have a special strategy that helps you to do that? }\end{array}$ \\
\hline P & $\begin{array}{l}\text { I usually write it down somewhere. I have made a list of new words in my notebook, so I add it to } \\
\text { the list. We add new words to the list by ourselves and the teacher explains them to us. }\end{array}$ \\
\hline
\end{tabular}

\section{BЕРА М. САВИТ}

УНИВЕРЗИТЕТ У КРАГУЈЕВЦУ ФАКУЛТЕТ ПЕДАГОШКИХ НАУКА У ЈАГОДИНИ

КАТЕДРА ЗА ФИЛОЛОШКЕ НАУКЕ

ДАНИЈЕЛА М. ПРОШИЋ-САНТОВАЦ

УНИВЕРЗИТЕТ У НОВОМ САДУ

ФИЛОЗОФСКИ ФАКУЛТЕТ

ОДСЕК ЗА АНГЛИСТИКУ

РЕЗИМЕ

ПРИМЕНА КВАЛИТАТИВНИХ МЕТОДА У ЛИНГВИСТИЧКИМ

ИСТРАЖИВАЮИМА СА ДЕЦОМ: ИЗАЗОВИ И ПЕРСПЕКТИВЕ СПРОВОЪЕЊА ИНТЕРВЈУА СА ДЕЦОМ ПРЕДШКОЛСКОГ И МЛАБЕГ ШКОЛСКОГ УЗРАСТА

Данас се све више препознаје значај и применљивост квалитативних метода у језичким истраживањима, посебно у области усвајања страног или другог језика (енгл. L2). У области наставе енглеског језика као страног/другог језика на млађем узрасту, квалитативни приступи сматрају се посебно погодним јер омогућавају стицање увида у дечије разумевање сопственог учења. Рад има за циљ да одговори на бројна питања која су релевантна за примену квалитативних истраживања са децом у настави енглеског као страног или другог језика. Примењена је метода анализе интервјуа коришћених у два новија истраживања у Србији, као што су: вербални протокол спроведен са ученицима старим 11 година ради проучавања вештине почетног читања (Савић, 2017) и структурирани интервју спроведен у студији случаја учење енглеског језика употребом популарних цртаних филмова на узрасту од четири године (Прошић-Сантовац, 2017). Прва студија спроведена је са 12 ученика млађег узраста која има за циљ да утврди питања релевантна за вештину читања на страном језику, док је друго истраживање фокусира- 
но на студију случаја у којој је примењен структуирани интервју у вези са популарним цртаним филмом коришћењем у настави и учењу енглеског језика. Педагошке импликације сумиране су као изазови и могућности примене интервјуа у истраживањима са децом млађег школског и предшколског узраста. Посебно су наглашене перспективе које су у вези са стицањем дубљег разумевања дечијег језичког развоја. Закључује се да спровођење интервјуа у истраживањима са децом омогућава осветљавање индивидуалних и контекстуалних фактора који утичу на ефикасност наставе и усвајања страног/другог језика на предшколском и млађем школском узрасту.

КљУчнЕ РЕчи: ученици енглеског језика млађег узраста; квалитативна истраживања; интервју; верठални протокол; студија случаја.

Овај чланак је објављен и дистрибуира се под лиценцом Creative Commons Ауторство-Некомерцијално Међународна 4.0 (CC BY-NC 4.0|

https://creativecommons.org/licenses/by-nc/4.0/).

This paper is published and distributed under the terms and conditions of the Creative Commons Attribution-NonCommercial International 4.0 licence (CC BY-NC 4.0 | https://creativecommons.org/licenses/by-nc/4.0/). 